\title{
A review of fuzzy methods in automotive engineering applications
}

\author{
Valentin Ivanov ${ }^{1}$ (iD \\ Received: 26 October 2014 / Accepted: 18 August 2015 /Published online: 27 August 2015 \\ (C) The Author(s) 2015. This article is published with open access at SpringerLink.com
}

\begin{abstract}
Purpose The paper addresses evolution of fuzzy systems for core applications of automotive engineering.

Methods The presented study is based on the analysis of bibliography dedicated to fuzzy sets and fuzzy control for ground vehicles. A special attention is given to fuzzy approaches used in the following domains of automotive engineering: vehicle dynamics control systems, driver and driving environment identification, ride comfort control, and energy management of electric vehicles.

Results The bibliographical analysis, supplemented with statistics of relevant research publications, has allowed to allocate the most important fuzzy application cases for each domain. In particular, it concerns driver identification, humanmachine interface, recognition of road conditions, and controllers of vehicle chassis and powertrain systems. It is found out that fuzzy methods have the primary use most of all for tasks requiring identification and forecasting procedures, especially in conditions of limited informational space. Additional observation that can be also derived from the presented survey points to reasonable integration of fuzzy technique with other control engineering methods to improve the performance of automotive control systems.

Conclusions In the aggregate the performed review indicates that fuzzy computing can be considered as a versatile tool for automotive engineering applications of different nature.
\end{abstract}

Valentin Ivanov

valentin.ivanov@tu-ilmenau.de

1 Automotive Engineering Group, Ilmenau University of Technology, Ehrenbergstr. 15, 98693 Ilmenau, Germany
Keywords Fuzzy systems · Road vehicles · Automotive control systems · Vehicle dynamics control · Electric vehicles

\section{Introduction}

Fuzzy logic, among other computational intelligence methods, attracts increased attention of engineers and researchers involved in the development of complex control solutions for road vehicles and their subsystems. A possibility to overcome various nonlinear models and to use intuitive logical rules makes fuzzy control and fuzzy identification procedures useful tools by rapid system prototyping and on early design stages. It is of particular relevance for intelligent vehicle functions and systems requiring the prediction of manoeuvres dynamics, identification of driving environment parameters and objects, and interaction with the driver. For the mentioned topics, the development of models of objects and relevant controllers of on-board systems can meet essential problems with feasibility, sufficient level of complexity and other features demanded for real-time automotive applications. These issues can be efficiently handled with the computational intelligence methods, which are known as reasonable and powerful tools in solving non-well-posed analytical problems. Among different computational intelligence methods like neural networks, swarm intelligence computing et al. the fuzzy logic can be of special relevance for intelligent automotive systems. The reason is that the fuzzy logic has good applicability for identification tasks and pre-emptive control under strong presence of data and model uncertainty.

The above-listed arguments are motivated the study outlined in this paper. The main goal of the study is to give a survey of existing fuzzy methods and systems that are finding applications in the automotive area. Because the subject of the study is characterized by a high degree of interdisciplinarity, 
the discussed review can be of particular interest for researchers working on topics of Ground Vehicle Engineering, Control Engineering, and Computational Intelligence. Specific objectives of the presented work can be formulated as follows:

- Define research topics that are most relevant to automotive fuzzy systems and tools;

- Identify the main application cases for each defined topic;

- Estimate development trends for each defined topic;

- Analyse particular matters of automotive fuzzy systems from viewpoint of (i) industrial applications and (ii) integration with other control techniques.

The results of the performed survey are given in next sections in accordance with the listed objectives. The article includes also extensive bibliography aimed at the representation of various research schools around the world in context of the discussed topics.

\section{Review background}

The history of fuzzy systems in vehicle-related areas begins with several research works of founders of fuzzy logic dedicated to practical applications of fuzzy sets. An example is the intersection controller that reduced junction-related delay of vehicle driving proposed by Pappis and Mamdani in [1]. Later Sugeno and Murakami in [2] and Sugeno and Nishida in [3] have introduced the fuzzy realization of driver's logic for the cases of an automated car parking system and handling the desired vehicle trajectory. Then, from early 1990s, more and more automotive systems with fuzzy logic are subjected both to academic and industrial areas. This resulted in a considerable amount of publications and patents.

An analysis of the published studies and works allows to allocate a number of domains, where fuzzy logic has found the most acceptance. These domains can be conditionally called as "Driver", "Vehicle Dynamics", "Ride comfort", "Electric vehicles", and "Driving environment". Results of analysis of publications relevant to the fuzzy modeling and control of automotive systems in the listed engineering areas are further introduced in the paper.

The presented review uses the methodology proposed and partially implemented in [4]. The analysis uses only Englishlanguage scientific publications found in Scopus abstract and citation database of peer-reviewed literature (http://www. elsevier.com/online-tools/scopus). The following limitations of the analysis are accepted within the framework of this paper: The works are analyzed in relation to the ground and road vehicles only. Mobile robots and machines with nonholonomic constraints are excluded from the analysis due to their less relevance to automotive applications.
The overview is accompanied by statistics of peerreviewed journal articles from two recent decades (dated 1994-2013) in each domain. (Conference papers are excluded from statistical analysis to avoid the consideration of duplicated content. The elimination has been also done for those papers, which content was already published in another journal. This is because it was observed that in particular cases the same content is repeated with minor variations in several conference papers published by the same authors.)

Additional section of the paper will analyse the publications of SAE International (http://www.sae.org) as one of the most recognized informational source worldwide for automotive engineering and presenting mainly the studies, which are providing experimental verification and close to industrial application.

\section{Fuzzy methods for driver modelling and driver assistance systems}

The domain "Driver", proposed for the classification, implicates topics related to the driver models, driver behavior, and driver assistance systems. These topics are of special relevance for fuzzy applications because almost emotional and psychological facets of human behavior carry more semantic as numerical uncertainty. It complicates the formulation of the driver in simulation and control tasks through non-soft computing methods. The first applications of fuzzy sets to the modeling of the driver are arisen in 1980s. In particular, Kramer and Rohr in [5] and Kramer in [6] proposed to use a fuzzy model for the representation of perception characteristics of the driver and illustrated this approach on the driving simulator. Nagai, Kojima and Sato [7] suggested the fuzzy driver model describing the subjective recognition, judgment and control of the vehicle speed. This model was built from the accident analysis data. Then Kageyama and Pacejka [8] and Ehara and Suzuki [9] developed the first fuzzy models of the human reasoning for more complex driving situations. Analysis of relevant journal publications, Fig. 1, and conference papers allows to allocate the most typical applications of fuzzy methods within the domain „Driver“:

- Identifications and classifications of the drivers regarding fatigue, emotions and other human attributes, including the procedures of driver state recognition and forecasting through monitoring of various physiological parameters like electroencephalography-estimated brain activity, eye movement, gestures et al. [10-15],

- Structure and controllers of driver assistance systems and devices of human machine interface [16-18],

- Models of driver actions on vehicle controlling devices (brake and throttle pedals, steering wheel) for authentic 


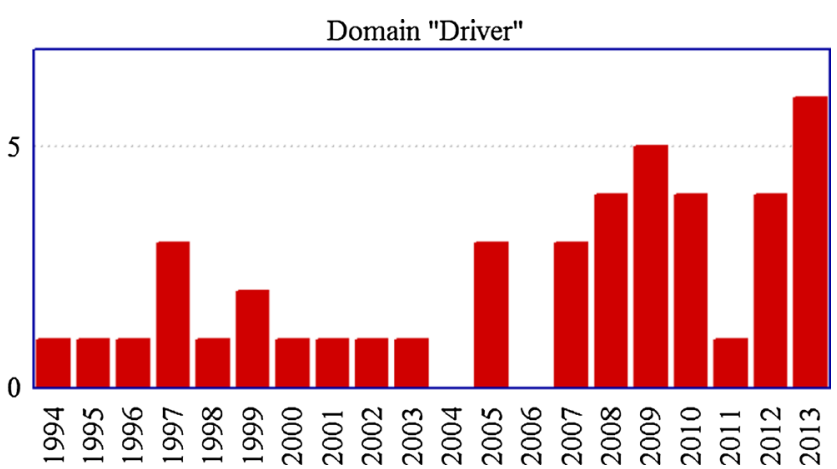

Fig. 1 Number of journal publications related to fuzzy methods in domain "Driver" and cited in Scopus database

simulation of vehicle maneuvers on driving simulators; controllers of pedal and steering wheel robots [19-22],

- Simulation of driver reasoning for controllers of (semi-) automated and unmanned ground vehicles [23-25],

- Understanding of subjective evaluation of vehicle dynamics; driver feeling of vehicle dynamics parameters like velocity, road friction and other [26-29],

- Advisory functions of human-machine interface systems supporting the driver in eco- and low-emission vehicle operation [30-32].

From practical viewpoint, the fuzzy logic gives valuable opportunity to develop controllers of human machine interface and driver assistance, which can be integrated with other automotive systems responsible for active safety control through the correction of vehicle dynamics by active chassis and powertrain subsystems. The controllers of these subsystems can also implement different fuzzy methods that will be discussed in next section.

\section{Fuzzy methods for vehicle dynamics control and ride comfort}

Within the framework of the presented review the domain "Vehicle Dynamics" relates to the systems controlling the lateral and longitudinal vehicle motion. The corresponding representatives are anti-lock braking (ABS) and traction control systems, torque vectoring, electronic stability control, electronic differentials et al. The systems responsible for the vertical dynamics of the vehicle are allocated to another domain "Ride Comfort" due to considerable amount of relevant publications. Statistics of journal papers for both mentioned domains is depicted in Figs. 2 and 3.

The first applications of fuzzy methods to the vehicle dynamics were related to the formalization of tire parameters, which are used in the brake and acceleration control. It can be explained with the fact that automotive tires have nonlinear characteristics of friction and slip, which cannot be measured by on-board sensors and require therefore real-time estimation with the help of

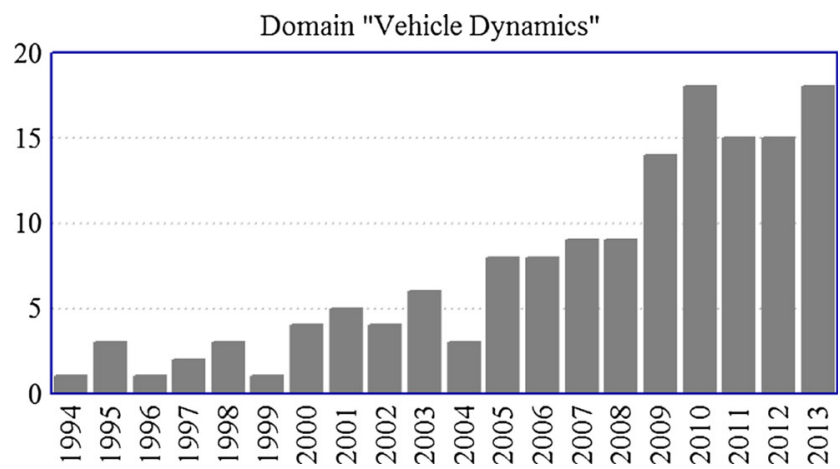

Fig. 2 Number of journal publications related to fuzzy methods in domain "Vehicle Dynamics" and cited in Scopus database

various numerical methods. Several early examples of fuzzy computing for tire parameters estimation are described in works of Stumpf, Arendt and Lux [33], and Madau, Yuan, Davis Jr. and Feldkamp [34]. Among vehicle dynamics control systems, ABS belongs to the classical examples of automotive control applications to verify and to define functional properties of different control methods, including fuzzy computing. In particular, Intel Corporation has proposed MCS 96 microcontroller family for the first fuzzy braking processors [35]. Later Siemens $A G$ has applied fuzzy coprocessors C99A for brake-by-wire systems [36]. Progress in vehicle dynamics control (VDC) systems has given many opportunities for practical implementation of fuzzy logic. Whereas the first VDC systems have used only brakes and engine as actuators, the actual trend is to enable other chassis systems such as steering and suspension in an integrated control circuit. As a result, the domain "Vehicle Dynamics" includes a series of the research problems where fuzzy methods found use:

- Brake control including architecture and algorithms of anti-lock braking systems [37-40]

- Vehicle traction control including solutions for engine control, electronic differentials, powertrain and driveline control in general [41-43],

- Control of lateral vehicle dynamics, in particular, in terms of yaw rate and vehicle sideslip control [44-48],

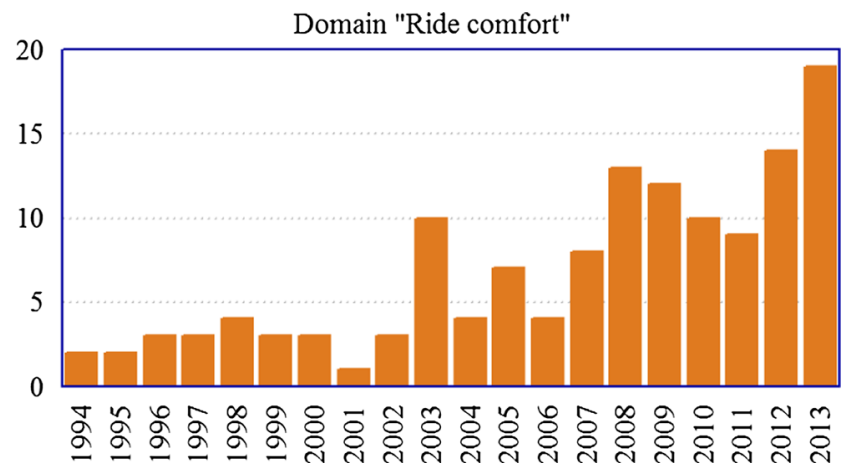

Fig. 3 Number of journal publications related to fuzzy methods in domain "Ride Comfort" and cited in Scopus database 
- Steering control including solutions for electric power steering; active front and rear steering [49-51]

- Estimation of vehicle state (linear velocity, yaw rate, vehicle sideslip angle et al.) from the sensors and experimental data [52-54],

- Integrated sequential or parallel control on vehicle dynamics through independent subsystems (e.g. brakes, steering, suspension, driveline) [55-58],

- Identification and estimation of parameters of tire-road interaction [59-63].

It was found during the analysis of research literature that studies of semi-active and active suspension control take up a larger share comparing with publications in other of automotive systems based on fuzzy methods. The reason can be that the ride control systems are characterized by complex nonlinear oscillating behaviour influencing simultaneously several properties like comfort, handling, or NVH (noise, vibration, harshness). The use of soft computing methods can certainly simplify the control on these vehicle properties. The earliest variants of fuzzy architecture of active suspension controllers were proposed by Yester and McFall [64], and Lin and Lu [65]. Then many other studies related to the fuzzy applications in the domain "Ride comfort" are arisen with the trend to continuous growth of research in this area. The main topics within the domain "Ride comfort" can be subjected as follows:

- Methods of objective evaluation and control of the vehicle ride comfort [66-68],

- Control algorithms of suspension actuators and shock absorbers with adaptation to environmental and operational conditions such as road roughness, vehicle dynamic variables and other [69-73]

- Special control strategies of electrorheological, magnetorheological, and electrical dampers and specific suspension elements [74-77].

It should be noted that in spite of numerous publications in the domain "Ride comfort", there are few reports about industrial variants of fuzzy suspension controllers. Overwhelming majority of analyzed investigations belongs to the fundamental or conceptual applied research.

Now many classes of ground vehicles require the mandatory installation of VDC systems. This fact can encourage more intensive investigations on fuzzy approaches in vehicle dynamics and ride control.

\section{Fuzzy methods and vehicle-environment interaction}

Both driver assistance and vehicle dynamics control systems, discussed in previous sections, can benefit from new information and communication technologies allowing closer interaction of the vehicle with the driving environment. Impactful control solutions improving vehicle safety and energy efficiency are being proposed now with the help of various on-board and on-road sensors as well road infrastructure services. All these aspects including the technologies for (semi-)autonomous driving are subjected to the domain "Driving Environment", which has been also analysed in the presented study, Fig. 4. It should be mentioned that specific topics of traffic control and architecture of Intelligent Transport Systems are excluded from the review because they are related mainly to Transport Engineering, but not to Automotive Engineering.

The first research works relevant to fuzzy systems in the domain "Driving Environment" have investigated path planning algorithms for an autonomous vehicle supported by a navigation system or equipped with advanced set of sensors, which are able to percept external parameters like distance between the vehicles or to identify external objects. The studies of Hogle and Bonissone [78] and Freisleben and Kunkelmann [79] can be mentioned in this context. These and other topics are in scope of standing research interest from middle of 1990s and now the main subjects of fuzzy applications for the domain "Driving Environment" can be classified as follows:

- Adaptive cruise control for the vehicles controlled by the driver; road following control for automated driving; collision prevention systems [80-82],

- Processing sensor information; recognition of driving environment parameters; vehicle localization [83-89],

- Coordination of road vehicle platoon systems [90-92],

- Control architecture of autonomous vehicles [93-96];

- Specific problems of brake, traction and steering control systems of autonomous vehicles [97-99];

- Automated parking systems [100-102].

In accordance with the short- and long-term projection, the mass-produced cars with functions of autonomous driving

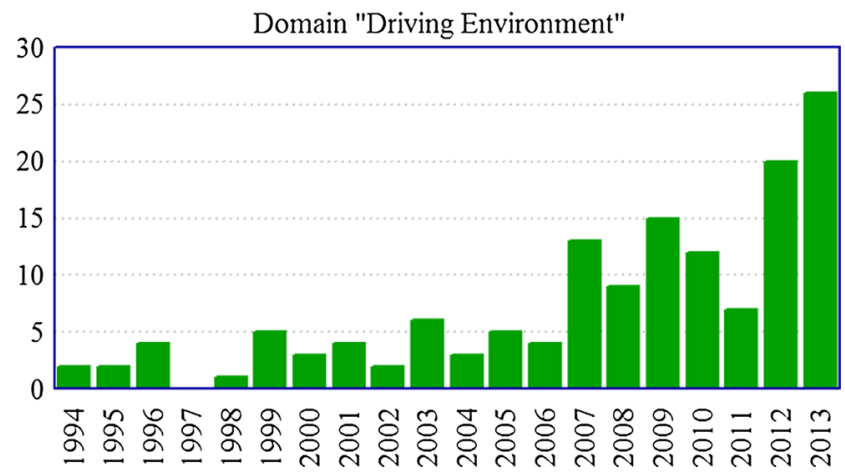

Fig. 4 Number of journal publications related to fuzzy methods in domain "Driving Environment" and cited in Scopus database 
will be stepwise introduced on the market in coming decade. This fact should stimulate more intensive research in various topics of the domain "Driving Environment".

\section{Fuzzy methods for electric vehicles}

Hybrid electric vehicles, full electric vehicles, fuel cell electric vehicles are at the centre of permanent attention of researchers and developers of fuzzy systems. This tendency is growing now because of sweeping development of technologies for "Green Mobility", Fig. 5. Early studies have introduced fuzzy energy management (EM) of electric vehicles in general. In particular, Farrall and Jones in [103] and Cerruto, Consoli, Raciti and Testa in [104] have proposed different fuzzy EM systems for hybrid vehicle, which were responsible for efficient powertrain control. Then, comparing with other automotive applications, fuzzy methods found many-sided use in the domain "Electric vehicles". An analysis of relevant research works allows to mention the following applicative areas for fuzzy methods:

- Global energy management of electric vehicles; hybrid powertrain control of operational modes (internal combustion engine / electric motor) [105-110];

- Traction control, anti-lock braking and regenerative braking control of electric vehicles [111-113];

- Internal controllers of electric motors, starters, inverters; electric propulsion controllers [114-116];

- Forecast and optimization of driving range [117, 118];

- Estimation of battery performance and algorithms for battery charging [119-121].

A number of other aspects like interaction of electric vehicles with the road and urban infrastructure are among further promising fuzzy applications in this research area.

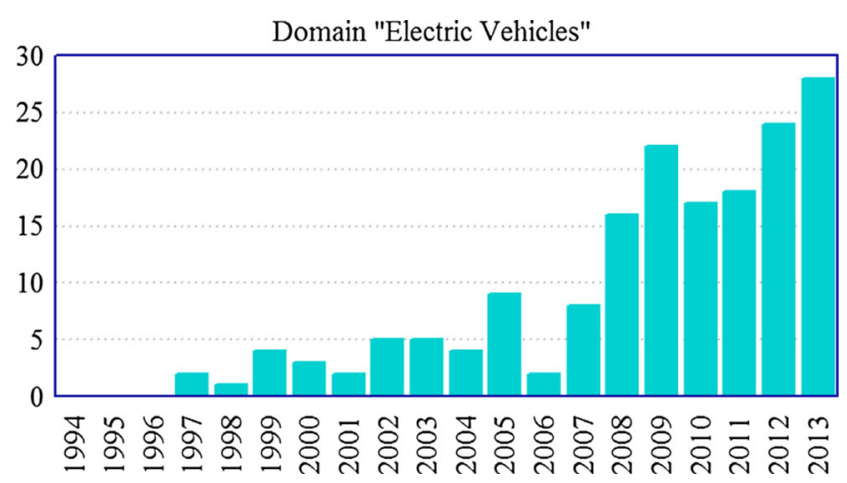

Fig. 5 Number of journal publications related to fuzzy methods in domain "Electric Vehicles" and cited in Scopus database

\section{Fuzzy methods for miscellaneous applications}

In addition to previously introduced domains, various unclassified or rarely studied examples of automotive fuzzy systems are also presented in analyzed research publications.

In particular, the most interesting variants cover the following topics: Transmission control including gear shifting algorithms and clutch control [122], Systems for diagnosing different vehicle systems and elements [123-125], Methods for the assessment of passive safety [126, 127], Thermal and NVH comfort control systems [128, 129], Vehicle body design [130], etc. Figure 6 shows the statistics of relevant journal publications. Hence, fuzzy methods can be considered as well-established research tools in different aspects of automotive engineering.

\section{Fuzzy methods in applied and industrial research}

One of the interesting results of the analysis is that a serious gap still persists between pure research and industrial applications of fuzzy methods in automotive engineering. To support this statement, Fig. 7 displays statistics of publications related to industrial or readyto-installation specimens of road vehicle systems with fuzzy controllers or fuzzy models embedded into the processing units. This selection reflects the analysis of technical papers published by SAE International as one of the most recognized information sources worldwide for automotive engineering. The preliminary search has found only few publications every year with information about application of fuzzy methods in automotive area. The deep analysis detected neither the clear-cut growth of fuzzy applications nor their regularity in individual domains. The reason for the available gap between theoretical studies and industrial systems can be explained by the fact that most of traditional automotive control systems have well-established variants of system architecture and corresponding real-time functional

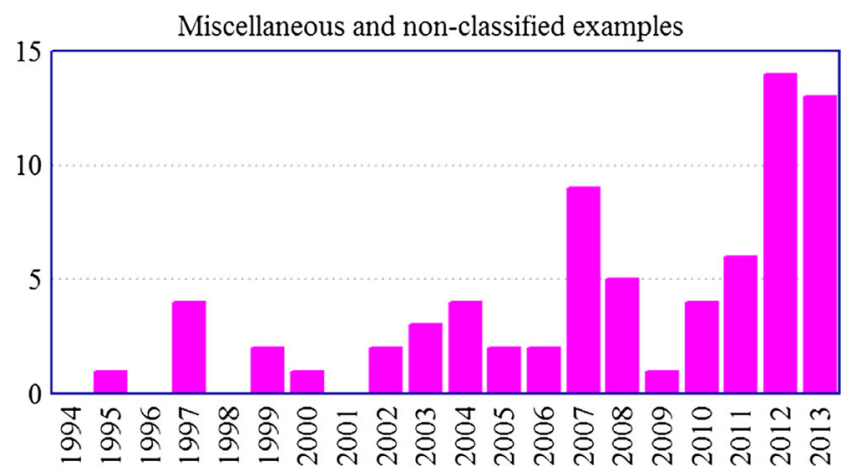

Fig. 6 Number of journal publications related to fuzzy methods for miscellaneous automotive applications and cited in Scopus database 
Fig. 7 Selected SAE publications related to fuzzy methods

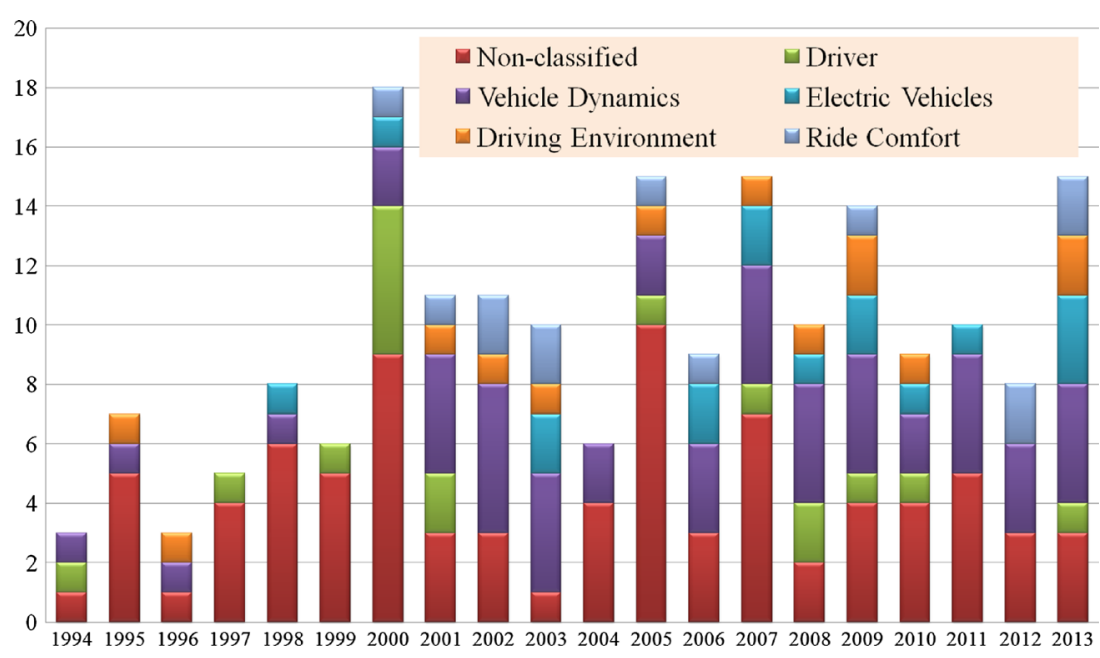

realizations, which are most often based on rule-based, nonlinear, optimal and other control approaches that are not directly related to computational intelligence methods. Therefore, until recently the progress in the vehicle control systems has been related first of all to the implementation of more powerful and efficient hardware accompanied with cautious modification of software part. However an increased demand for on-board systems, communicating with the driver and performing adaptation and learning in accordance with human behaviour, shows certain limitations in traditional, non-soft computing control techniques.

Nevertheless, it should be noted that some applicative areas for fuzzy methods are especially most commonly addressed in published industrial research studies. This is particularly true for on-board systems like the cruise control, lane change assistant et al., which require identification of the driver behaviour. The research of Ford Motor on the driver characterization for the car following $[131,132]$ and for the vehicle destination prediction [133] can be mentioned in this regard. A reasonable applicability of fuzzy methods to this topic has been also demonstrated in studies with the participation of Centro Richerce Fiat for the driver distraction modelling [134]. Other work [135], performed under coordination of researchers from Renault, has indicated an efficient implementation of fuzzy sets and fuzzy space windowing for the psychophysiological characterization of drivers within the context of the car following.

An analysis of industrial white papers and analytical publications indicates trends to further consistent growth of intelligent automotive systems with the logic based on fuzzy methods [136]. This statement can be also confirmed with numerous industrial patents for fuzzy algorithms and controllers, claimed by automotive OEMs and suppliers. It allows to expect that the mentioned gap between pure research and industrial applications should be overcome in near future.

\section{About compatibility of fuzzy methods in automotive engineering}

Eventual barriers for more intensive dissemination of fuzzy methods in automotive engineering can be removed through their integration with other analytical and numerical methods. In particular, such integration can improve robustness and adaptivity of controllers with simultaneous keeping of straightforward formalization of control tasks. The fact that fuzzy logic remains one of the most inviting approaches in basic and applied sciences it can be supported by the important indicator of high compatibility of fuzzy methods with other computing and control techniques. The analyzed research publications offer many examples of integration of fuzzy sets and fuzzy logic that are summarized in Table 1.

\section{Conclusions}

Analysis of research literature, especially results of published experimental works, demonstrates that fuzzy methods have solid background and good prospects for the implementation

Table 1 Examples of methods used in automotive applications

\begin{tabular}{ll}
\hline Conventional fuzzy methods & $\begin{array}{l}\text { Methods / tools integrated } \\
\text { with fuzzy technique }\end{array}$ \\
\hline Takagi-Sugeno fuzzy model [137] & $\begin{array}{l}\text { Sliding mode control [141] } \\
\text { Fuzzy linear regression [9] }\end{array}$ \\
Fuzzy preview control [138] & PI and PID control [91, 143] \\
Model reference adaptive fuzzy & Genetic algorithm [71, 144] \\
$\quad$ control [44] & Optimization gradient method [145] \\
Neuro-fuzzy method [123] & Multi-objective optimization [108] \\
Hierarchical fuzzy integral [24] & Variable structure control [146] \\
Fuzzy clustering [139] & Reinforcement learning [94] \\
Type-II fuzzy system [140] & Bayesian methods [147] \\
\hline
\end{tabular}


in automotive engineering applications. The following positions can be especially mentioned in this context:

- For the selected topics each-Driver, Vehicle Dynamics Control, Electric Vehicles, Driving Environment-the analysis has discovered a series of fuzzy application cases of different nature that points to good versatile and flexible feasibility of fuzzy methods for automotive engineering tasks;

- Relevant publication statistics indicates continuous growth of fuzzy-related research activities in the selected topics each;

- Despite the currently available gap between theoretical research and industrial implementations, a strong demand in automotive systems with intelligent functions and involving more intuitive interaction with the driver and environment will stimulate a more wide adoption of fuzzy tools and systems on serial vehicles.

The most feasible breakthrough in further development of fuzzy systems and tools for automotive engineering applications can be expected from two kinds of "fusion". From theoretical side, the fusion of fuzzy methods with other methods of soft computing or nonlinear control opens very promising prospects. From technological side, the fusion of many vehicle controllers and estimators on common fuzzy basis can get over numerical and linguistic uncertainties accompanying complex processes of vehicle dynamics and vehicle-driverenvironment interaction. These trends would encourage the researchers and engineers in seeking for novel applicative fuzzy solutions in automotive engineering.

Open Access This article is distributed under the terms of the Creative Commons Attribution 4.0 International License (http:// creativecommons.org/licenses/by/4.0/), which permits unrestricted use, distribution, and reproduction in any medium, provided you give appropriate credit to the original author(s) and the source, provide a link to the Creative Commons license, and indicate if changes were made.

\section{References}

1. Pappis CP, Mamdani EH (1977) A fuzzy logic controller for a traffic junction. IEEE Trans Syst Man Cybernet SMC-7(10): 707-717

2. Sugeno M, Murakami K (1984) Fuzzy parking control of model car, Proc. IEEE Conf Decis Control, pp. 902-903

3. Sugeno M, Nishida M (1985) Fuzzy control of model car. Fuzzy Sets Syst 16:103-113

4. Ivanov V (2001) Fuzzy methods in ground vehicle engineering : state-of-the-art and advanced applications, in Proc. 8th International Conference on Structural Dynamics, EURODYN 2011, Leuven, Belgium, paper MS19-270

5. Kramer U, Rohr G (1982) A model of driver behaviour. Ergonomics 25(10):891-907
6. Kramer U (1985) On the application of fuzzy sets to the analysis of the system driver-vehicle-environment. Automatica 21(1):101-107

7. Nagai M, Kojima Y, Sato H (1987) Driver's decision and control process during right-turning at intersections (application of fuzzy linguistic model for accident analysis), SAE Technical Papers Series, paper no. 871250

8. Kageyama I, Pacejka HB (1991) On a new driver model with fuzzy control. Veh Syst Dyn 20(suppl 1):314-324

9. Ehara N, Suzuki K (1991) Estimation of human reasoning state in machine operation using fuzzy linear regression. Trans Jpn Soc Mech Eng Part C 57:3907-3912

10. Lin C-T, Tsai S-F, Ko L-W (2013) EEG-based learning system for online motion sickness level estimation in a dynamic vehicle environment. IEEE Trans Neural Netw Learn Syst 24(10):16891700 , art. no. $\mathbf{6 5 8 7 6 0 0}$

11. Kuhn K-P, Heidinger A (1997) On-line driver type classification. Int J Veh Des 18(6):616-625

12. Lee D, Donnell ET (2007) Analysis of nighttime driver behavior and pavement marking effects using fuzzy inference system. J Comput Civ Eng 21(3):200-210

13. Wu J-D, Chen T-R (2008) Development of a drowsiness warning system based on the fuzzy logic images analysis. Expert Syst Appl 34(2):1556-1561

14. Boyraz P, Acar M, Kerr D (2008) Multi-sensor driver drowsiness monitoring. Proc IMechE Part D J Automob Eng 222(11):1857-1878

15. Wahab A, Quek C, Tan CK, Takeda K (2009) Driving profile modeling and recognition based on soft computing approach. IEEE Trans Neural Netw 20(4):563-582

16. Maeda M (1995) Fuzzy drive expert system for an automobile. Inf Sci Appl 4(1):29-48

17. Willumeit H-P (1997) Driver models: how to avoid critical yaw movements of vehicles. Int J Veh Des 18(6):652-667

18. Nigro J-M, Loriette-Rougegrez S, Rombaut M (2002) Driving situation recognition with uncertainty management and rulebased systems. Eng Appl Artif Intell 15(3-4):217-228

19. Hong C-W, Shio T-W (1996) Fuzzy control strategy design for an autopilot on automobile chassis dynamometer test stands. Mechatronics 6(5):537-555

20. Hong C-W (1997) Tuning the fuzzy control autopilot strategy for driving pattern simulation of road vehicles. Int J Veh Des 18(1):35-52

21. Lee MC, Park MK, Yoo WS, Son K, Han MC (2003) Sliding mode control of real-time PNU vehicle driving simulator and its performance eveluation. JSME Int J Ser C Mech Syst Mach Elem Manuf 46(2):557-564

22. Takahashi H, Ukishima D, Kawamoto K, Hirota K (2007) A study on predicting hazard factors for safe driving. IEEE0 Trans Ind Electron 54(2):781-789

23. Matthews ND, An PE, Roberts JM, Harris CJ (1998) A neurofuzzy approach to future intelligent driver support systems. Proc IMechE Part D J Automob Eng 212(1):43-58

24. Takahashi H, Kuroda K (1999) Intelligent vehicle control considering driver's visual perception, Proc. IEEE Conference on Intelligent Transportation Systems, pp. 252-257

25. Chen G, Zhang W-G, Zhang X-N (2013) Fuzzy neural control for unmanned robot applied to automotive test. Ind Robot 40(5):450 461, art. no. 17094477

26. Laurence P, Basset M, Coutant P, Gissinger G (2000) Lateral vehicle behaviour: comparison of subjective/objective assessment using the Choquet integral. Veh Syst Dyn 34(5):357-379

27. Ma X, Andréasson I (2007) Statistical analysis of driver behavior data in different regimes of the car-following stage. Transportation Research Record, no. 2018, pp. 87-96

28. Moridpour S, Rose G, Sarvi M (2009) Modelling the heavy vehicle drivers' lane changing decision under heavy traffic conditions. Road Transp Res 18(4):49-57 
29. Hurwitz DS, Wang H, Knodler MA Jr, Ni D, Moore D (2012) Fuzzy sets to describe driver behavior in the dilemma zone of high-speed signalized intersections. Transport Res F: Traffic Psychol Behav 15(2):132-143

30. Vangi D, Virga A (2003) Evaluation of energy-saving driving styles for bus drivers. Proc IMechE Part D J Automob Eng 217(4):299-305

31. Syed FU, Filev D, Ying H (2007) Fuzzy rule-based driver advisory system for fuel economy improvement in a hybrid electric vehicle, Proc. of Annual Conference of the NAFIPS, no. 4271056, pp. $178-183$

32. Luu HT, Nouvelière L, Mammar S (2010) Ecological and safe driving assistance system: Design and strategy, Proc. of IEEE Intelligent Vehicles Symposium, no. 5548012, pp. 129-134

33. Stumpf H, Arendt G, Lux F (1988) Linking evaluation of subjective handling tests on the road with objectively measured data by using fuzzy-set-theory, SAE Technical Papers Series, paper no. 885006

34. Madau DP, Yuan F, Davis Jr LI, Feldkamp LA (1993) Fuzzy logic anti-lock brake system for a limited range coefficient of friction surface, 1993 I.E. International Conference on Fuzzy Systems, pp. 883-888

35. Gullett C, Elting D, Kowalczyk R, Fennich M, Hellenthal B (1995) Intel fuzzy logic tool simplifies ABS design, Intel Corporation Application Note, No. 272595-001, pp. 1-8

36. Eichfeld H, Mertens A, Brandmeier T, Waidelich F, Graumann R, Schwab M (1998) Applications of SAE 81C99x fuzzy coprocessors. Proc IEEE Int Conf Fuzzy Syst 1:19-24

37. Mauer GF (1995) Fuzzy logic controller for an ABS braking system. IEEE Trans Fuzzy Syst 3(4):381-388

38. Chen F-W, Liao T-L (2000) Nonlinear linearization controller and genetic algorithm-based fuzzy logic controller for ABS systems and their comparison. Int J Veh Des 24(4):334-349

39. Kim S, Kim H, Sung Y-G (2001) Electronic control of braking force distribution for vehicles using a direct adaptive fuzzy controller. KSME Int J 15(1):66-80

40. Kuti I (2004) An adaptive fuzzy control to antilock non-straight line braking using three dimensional (finite element) vehicle model. Int J Veh Des 34(4):327-339

41. Klaus K, Hasemann M (1995) An embedded fuzzy anti-slippage system for heavy duty off road vehicles. Inf Sci Appl 4(1):1-27

42. Hiller M, Schmitz T, Schuster C (1996) Design of a fuzzy traction control system using spatial vehicle dynamics simulation. Heavy Veh Syst 3(1-2):240-248

43. Trebi-Ollennu A, Dolan JM, Khosla PK (2001) Adaptive fuzzy throttle control for an all-terrain vehicle. Proc IMechE Part I J Syst Control Eng 215(3):189-198

44. Hessburg T, Tomizuka M (1995) An adaptation method for fuzzy logic controllers in lateral vehicle guidance. Mechatronics 5(8): 873-898

45. Boada BK, Boada MJL, Díaz V (2005) Fuzzy-logic applied to yaw moment control for vehicle stability. Veh Syst Dyn 43(10): 753-770

46. Chadli M, El Hajjaji A, Oudghiri M (2008) Robust output fuzzy control for vehicle lateral dynamic stability improvement. Int $\mathrm{J}$ Model Identif Control 3(3):247-257

47. Du H, Zhang N, Smith W (2009) Robust yaw moment control for vehicle handling and stability. SAE Int J Passenger Cars Mech Syst 2(1):772-779

48. Ivanov V, Shyrokau B, Augsburg K, Gramstat S (2010) Advancement of vehicle dynamics control with monitoring the tire rolling environment. SAE Int J Passenger Cars Mech Syst 3(1):199-216

49. Szosland A (2000) Fuzzy logic approach to four-wheel steering of motor vehicle. Int J Veh Des 24(4):350-359
50. Huh K, Kim J (2001) Active steering control based on the estimated tire forces. J Dyn Syst Meas Control Trans ASME 123(3): 505-511

51. Jalali K, Uchida T, McPhee J, Lambert S (2013) Development of an advanced fuzzy active steering controller and a novel method to tune the fuzzy controller. SAE Int J Passenger Cars Electron Electr Syst 6(1):241-254

52. Basset M, Zimmer C, Gissinger GL (1997) Fuzzy approach to the real time longitudinal velocity estimation of a FWD car in critical situations. Veh Syst Dyn 27(5-6):477-489

53. Hwang JK, Song CK (2005) Fuzzy estimation of vehicle speed using an accelerometer and wheel sensors. Int $\mathrm{J}$ Automot Technol 6(4):359-365

54. Cheli F, Sabbioni E, Pesce M, Melzi S (2007) A methodology for vehicle sideslip angle identification: comparison with experimental data. Veh Syst Dyn 45(6):549-563

55. Zeyada YF, Elbeheiry EM, Elarabi ME (2000) Fault diagnosis and $\mu$-estimation for integrated chassis control of vehicles in emergency maneuvers. J Eng Appl Sci 47(4):665-681

56. Yoshimura T, Emoto Y (2003) Steering and suspension system of a full car model using fuzzy reasoning and disturbance observers. Int J Veh Auton Syst 1(3-4):363-386

57. March C, Shim T (2007) Integrated control of suspension and front steering to enhance vehicle handling. Proc IMechE Part D J Automob Eng 221(4):377-391

58. Song J (2012) Integrated control of brake pressure and rear-wheel steering to improve lateral stability with fuzzy logic. Int J Automot Technol 13(4):563-570

59. Ergun M (2007) Estimation of friction coefficient of asphalt concrete road surfaces using the fuzzy logic approach. Can J Civ Eng 34(9): 1110-1118

60. Shyrokau BN, Ivanov VG (2008) Alterable fuzzy sets in automotive control applications. Int J Model Identif Control 3(3):305-317

61. Li L, Song J, Li H-Z, Shan D-S, Kong L, Yang CC (2009) Comprehensive prediction method of road friction for vehicle dynamics control. Proc IMechE Part D J Automob Eng 223(8):987-1002

62. Ivanov V, Shyrokau B, Augsburg K, Algin V (2010) Fuzzy evaluation of tyre-surface interaction parameters. J Terrramech 47(2): $113-130$

63. Ivanov V (2011) Fuzzy architecture of systems with alterable information: case study for tyre-ground friction estimators. Int J Reliab Saf 5(3/4):398-419

64. Yester JL, McFall RH (1992) Fuzzy logic controller for active suspension. Proc Soc Automot Eng P-260:259-270

65. Lin Y-J, Lu Y-Q (1993) Toward better ride performance of vehicle suspension systems via intelligent control. Am Soc Mech Eng Dyn Syste Control Div (Publ) DSC 48:105-112

66. Jianghong Z, Long T (1994) An evaluation of comfort of a bus seat. Appl Ergon 25(6):386-392

67. Eslaminasab N, Biglarbegian M, Melek WW, Golnaraghi MF (2007) A neural network based fuzzy control approach to improve ride comfort and road handling of heavy vehicles using semiactive dampers. Int J Heavy Veh Syst 14(2):135-157

68. Suzuki T, Takahashi M (2010) Robust active suspension control for vibration reduction of passenger's body. Trans JSME Part C 76(762):380-387

69. Cherry AS, Jones RP (1995) Fuzzy logic control of an automotive suspension system. IEE Proc Control Theory Appl 142(2):149-160

70. Yoshimura T, Isari Y, Li Q, Hino J (1997) Active suspension of motor coaches using skyhook damper and fuzzy logic control. Control Eng Pract 5(2):175-184

71. Caponetto R, Diamante O, Fargione G, Risitano A, Tringali D (2003) A soft computing approach to fuzzy sky-hook control of semiactive suspension. IEEE Trans Control Syst Technol 11(6): 786-798 
72. Sie W-T, Lian R-J, Lin B-F (2006) Enhancing grey prediction fuzzy controller for active suspension systems. Veh Syst Dyn 44(5):407-430

73. Kaldas MMS, Çalișkan K, Henze R, Küçükay F (2013) Rule optimized fuzzy logic controller for full vehicle semi-active suspension. SAE Int J Passenger Cars Mech Syst 6(1):332-344

74. Choi S-B, Park D-W, Suh M-S (2002) Fuzzy sky-ground hook control of a tracked vehicle featuring semi-active electrorheological suspension units. J Dyn Syst Meas Control Trans ASME 124(1):150-157

75. Giuclea M, Sireteanu T, Stancioiu D, Stammers CW (2004) Model parameter identification for vehicle vibration control with magnetorheological dampers using computational intelligence methods. Proc IMechE Part I J Syst Control Eng 218(7):569-581

76. Zheng L, Li YN, Baz A (2009) Fuzzy-sliding mode control of a full car semi-active suspension systems with MR dampers. Smart Struct Syst 5(3):261-277

77. Lee S, Kim W-J (2010) Active suspension control with directdrive tubular linear brushless permanent-magnet motor. IEEE Trans Control Syst Technol 18(4):859-870, art. no. 5286231

78. Hogle RA, Bonissone PP (1994) Fuzzy algorithm for path selection in autonomous vehicle navigation. Proc IEEE Conf Decis Control:898-900

79. Freisleben B, Kunkelmann T (1993) Combining fuzzy logic and neural networks to control an autonomous vehicle, 1993 I.E. International Conference on Fuzzy Systems, pp. 321-326

80. Blöchl B, Tsinas L (1994) Automatic road following using fuzzy control. Control Eng Pract 2(2):305-311

81. Chakroborty P, Kikuchi S (1999) Evaluation of the general motors based car-following models and a proposed fuzzy inference model. Transp Res Part C Emerg Technol 7(4):209-235

82. Naranjo JE, González C, Reviejo J, García R, De Pedro T (2003) Adaptive fuzzy control for inter-vehicle gap keeping. IEEE Trans Intell Transp Syst 4(3):132-142

83. Qiao MS, Takeda H (1995) Learning algorithm of environmental recognition in driving vehicle. IEEE Trans Syst Man Cybernet 25(6):917-925

84. Stover JA, Hall DL, Gibson RE (1996) A fuzzy-logic architecture for autonomous multisensor data fusion. IEEE Trans Ind Electron 43(3):403-410

85. Goebel KF, Agogino AM (2001) Sensor validation and fusion for automated vehicle control using fuzzy techniques. J Dyn Syst Meas Control Trans ASME 123(1):145-146

86. Rigatos G, Tzafestas S (2007) Extended Kalman filtering for fuzzy modelling and multi-sensor fusion. Math Comput Model Dyn Syst 13(3):251-266

87. Kim SY, Choi HC, Won WJ, Oh SY (2009) Driving environment assessment using fusion of in- and out-of-vehicle vision systems. Int J Automot Technol 10(1):103-113

88. Broggi A, Cerri P, Ghidoni S, Grisleri P, Jung HG (2009) A new approach to urban pedestrian detection for automatic braking. IEEE Trans Intell Transp Syst 10(4):594-605, art. no. 5290131

89. Filev DP, Kolmanovsky I (2012) Markov chain modeling and onboard identification for automotive vehicles. Lect Notes Control Inf Sci 418:111-128

90. Bauer M, Tomizuka M (1996) Fuzzy logic traction controllers and their effect on longitudinal vehicle platoon systems. Veh Syst Dyn 25(4):277-303

91. Lee GD, Kim SW, Yim YU, Jung JH, Oh SY, Kim BS (1999) Longitudinal and lateral control system development for a platoon of vehicles, IEEE Conference on Intelligent Transportation Systems, Proceedings, ITSC, pp. 605-610

92. Kim K, Kim J, Huh KS, Yi K, Cho D (2006) A real-time multivehicle simulator for longitudinal controller design. Veh Syst Dyn 44(5):369-386
93. Pasquier M, Quek C, Toh M (2001) Fuzzylot: a novel selforganising fuzzy-neural rule-based pilot system for automated vehicles. Neural Netw 14(8):1099-1112

94. Dai X, Li CK, Rad AB (2005) An approach to tune fuzzy controllers based on reinforcement learning for autonomous vehicle control. IEEE Trans Intell Transp Syst 6(3):285-293

95. Milanés V, Villagrá J, Pérez J, González C (2012) Low-speed longitudinal controllers for mass-produced cars: a comparative study. IEEE Trans Ind Electron 59(1):620-628, art. no. 5759771

96. Pérez J, Milanés V, Godoy J, Villagrá J, Onieva E (2013) Cooperative controllers for highways based on human experience. Expert Syst Appl 40(4):1024-1033

97. Kim HM, Dickerson J, Kosko B (1996) Fuzzy throttle and brake control for platoons of smart cars. Fuzzy Sets Syst 84(3):209-234

98. Naranjo JE, Reviejo J, González C, García R, De Pedro T (2004) A throttle and brake fuzzy controller: towards the automatic car. Lect Notes Comput Sci (Incl Subseries Lec Notes Artif Intell Lect Notes Bioinforma 2809:291-301

99. Naranjo JE, González C, García R, De Pedro T, Haber RE (2005) Power-steering control architecture for automatic driving. IEEE Trans Intell Transp Syst 6(4):406-415

100. Ryu Y-W, Oh S-Y, Kim S-Y (2008) Robust automatic parking without odometry using an evolutionary fuzzy logic controller. Int J Control Autom Syst 6(3):434-443

101. Chen C-Y, Feng H-M (2009) Hybrid intelligent vision-based carlike vehicle backing systems design. Expert Syst Appl 36(4): 7500-7509

102. Shiao Y, Yu C-J (2012) Automatic parking control for vehicles with stereo vision. Adv Sci Lett 8:49-54

103. Farrall SD, Jones RP (1993) Energy management in an automotive electric/heat engine hybrid powertrain using fuzzy decision making, Proc. 1993 International Symposium on Intelligent Control, pp. 463-468

104. Cerruto E, Consoli A, Raciti A, Testa A (1994) Fuzzy logic based efficiency improvement of an urban electric vehicle. IECON Proc (Ind Electron Conf 2:1304-1309

105. Vermeiren L, Guerra TM, Paganelli G (1997) Application of fuzzy set theory to electric car control. Cybern Syst 28(8):675-693

106. Baumann BM, Washington G, Glenn BC, Rizzoni G (2000) Mechatronic design and control of hybrid electric vehicles. IEEE/ASME Trans Mechatron 5(1):58-72

107. Schouten NJ, Salman MA, Kheir NA (2002) Fuzzy logic control for parallel hybrid vehicles. IEEE Trans Control Syst Technol 10(3):460-468

108. Ippolito L, Loia V, Siano P (2003) Extended fuzzy C-means and genetic algorithms to optimize power flow management in hybrid electric vehicles. Fuzzy Optim Decis Making 2(4):359-374

109. Ahn H-S, Lee NS, Moon CW, Jeong G-M (2007) Fuel economy improvement for fuel cell hybrid electric vehicles using fuzzy logic-based power distribution control. Int J Automot Technol 8(5):651-658

110. Solano Martínez J, Mulot J, Harel F, Hissel D, Péra M-C, John RI, Amiet M (2013) Experimental validation of a type-2 fuzzy logic controller for energy management in hybrid electrical vehicles. Eng Appl Artif Intell 26(7):1772-1779

111. Yoshimura T, Uchida H, Nasu H, Hino J, Ueno R (1997) Traction force control of an electric vehicle in 2WS-4WD mode using fuzzy reasoning. Int J Veh Des 18(5):442-454

112. Pusca R, Ait-Amirat Y, Berthon A, Kauffmann JM (2002) Fuzzy logic based control for electric vehicle with four separate traction drives. Proc IEEE Veh Technol Conf 4:2089-2097

113. Kim D-H, Kim J-M, Hwang S-H, Kim H-S (2007) Optimal brake torque distribution for a four-wheel-drive hybrid electric vehicle stability enhancement. Proc IMechE Part D J Automob Eng 221(11):1357-1366 
114. Huang H (1999) Electrical two-speed propulsion by motor winding switching and its control strategies for electric vehicles. IEEE Trans Veh Technol 48(2):607-618

115. Sepe RB Jr, Miller JM (2002) Real-time collaborative experimentation via the internet: fuzzy efficiency optimization of a hybrid electric vehicle starter/alternator. Int J Veh Auton Szstems 1(1): 63-82

116. Ferreira AA, Pomilio JA, Spiazzi G, de Araujo Silva L (2008) Energy management fuzzy logic supervisory for electric vehicle power supplies system. IEEE Trans Power Electron 23(1):107115

117. Quigley CP, Ball RJ, Jones RP (2000) Fuzzy modelling approach to the prediction of journey parameters for hybrid electric vehicle control. Proc IMechE Part D J Automob Eng 214(8):875-885

118. Cunningham I, Burnham K (2013) Online use of the fuzzy transform in the estimation of electric vehicle range. Meas Control (UK) 46(9):277-282

119. Chau KT, Wu KC, Chan CC, Shen WX (2003) A new battery capacity indicator for nickel-metal hydride battery powered electric vehicles using adaptive neuro-fuzzy inference system. Energy Convers Manag 44(13):2059-2071

120. Albertus P, Couts J, Srinivasan V, Newman J (2008) A combined model for determining capacity usage and battery size for hybrid and plug-in hybrid electric vehicles. J Power Sources 183(2):771782

121. Fleischer C, Waag W, Bai Z, Sauer DU (2013) On-line self-learning time forward voltage prognosis for lithium-ion batteries using adaptive neuro-fuzzy inference system. J Power Sources 243:728749

122. Hayashi K, Shimizu Y, Dote Y, Takayama A, Hirako A (1995) Neuro fuzzy transmission control for automobile with variable loads. IEEE Trans Control Syst Technol 3(1):49-52

123. Halfmann C, Ayoubi M, Holzmann H (1997) Supervision of vehicles' tyre pressures by measurement of body accelerations. Control Eng Pract 5(8):1151-1159

124. Hissel D, Candusso D, Harel F (2007) Fuzzy-clustering durability diagnosis of polymer electrolyte fuel cells dedicated to transportation applications. IEEE Trans Veh Technol 56(5 I):2414-2420, art. no. 4305501

125. Kim MH, Lee S, Lee KC (2011) A fuzzy predictive redundancy system for fault-tolerance of $\mathrm{x}$-by-wire systems. Microprocess Microsyst 35(5):453-461

126. Murè S, Demichela M, Piccinini N (2006) Assessment of the risk of occupational accidents using a "fuzzy" approach. Cognit Technol Work 8(2):103-112

127. Mon Y-J (2007) Airbag controller designed by adaptive-networkbased fuzzy inference system (ANFIS). Fuzzy Sets Syst 158(24): 2706-2714

128. Khayyam H, Nahavandi S, Hu E, Kouzani A, Chonka A, Abawajy J, Marano V, Davis S (2011) Intelligent energy management control of vehicle air conditioning via look-ahead system. Appl Therm Eng 31(16):3147-3160

129. Nopiah ZM, Junoh AK, Ariffin AK (2013) Noise annoyance fuzzy index in passenger car cabin. Int J Veh Noise Vib 9(3-4): 216-233

130. Farkas L, Moens D, Donders S, Vandepitte D (2012) Optimisation study of a vehicle bumper subsystem with fuzzy parameters. Mech Syst Signal Process 32:59-60
131. Filev D, Lu J, Tseng F, Prakah-Asante K (2011) Real-time driver characterization during car following using stochastic evolving models, IEEE International Conference on Systems, Man and Cybernetics, pp. 1031-1036

132. Lu J, Filev D, Tseng F (2015) Real-time determination of driver's driving behavior during car following. SAE Int J Passenger Cars Electron Electr Syst, vol. 8, no. 2

133. D. Filev, F. Tseng, J. Kristinsson, and R. McGee, Real-time determination of driver's driving behavior during car following, IEEE Symposium on Computational Intelligence in Vehicles and Transportaion Systems, pp. 87-91, 2011

134. Tango F, Minin L, Tesauri F, Montanari R (2010) Field tests and machine learning approaches for refining algorithms and correlations of driver's model parameters. Appl Ergon 41(2):211-224

135. Dubart D, Loslever P, Popieul JC, Moessinger M (2011) Multiple correspondence analysis of fuzzyfied task performance and psycho-physiological test data: Use in real car following situations, 12th IFAC, IFIP, IFORS, IEA Symposium on Analysis, Design, and Evaluation of Human-Machine Systems

136. Gusikhin O, Filev D, Rychtyckyi N (2008) Intelligent vehicle system: Applications and new trends, Lecture Notes in Electrical Engineering, col. 15 , pp. 3-14

137. Dahmani H, Chadli M, Rabhi A, El Hajjaji A (2013) Vehicle dynamic estimation with road bank angle consideration for rollover detection: Theoretical and experimental studies. Veh Syst Dyn 51(12):1853-1871

138. Yeh EC, Tsao YJ (1994) Fuzzy preview control scheme of active suspension for rough road. Int J Veh Des 15(1-2):166-180

139. Cheok KC, Smid GE, McCune DJ (2000) Multisensor-based collision avoidance system with application to a military HMMWV, IEEE Conference on Intelligent Transportation Systems, Proceedings, ITSC, pp. 288-292

140. Economou JT, Colyer RE (2006) Fuzzy-hybrid modelling of an Ackerman steered electric vehicle. Int J Approx Reason 41(3): 343-368

141. Yang JH, Yang CC (2008) Adaptive sliding mode control for vehicle brake systems with fuzzy composition. Int J Model Identif Control 4(2):112-126

142. Chou J-H, Chen S-H, Lee F-Z (1998) Grey-fuzzy control for active suspension design. Int J Veh Des 19(1):65-77

143. Li Y, Ling Z, Liu Y, Qiao Y (2005) Method of fuzzy-PID control on vehicle longitudinal dynamics system, Lecture Notes in Artificial Intelligence, no. 3613 (PART I), pp. 822-832

144. Huang S, Ren W (1999) Use of neural fuzzy networks with mixed genetic/gradient algorithm in automated vehicle control. IEEE Trans Ind Electron 46(6):1090-1102

145. Kataoka H, Sado H, Sakai I, Hori Y (2001) Optimal slip ratio estimator for traction control system of electric vehicle based on fuzzy inference. Electr Eng Jpn (Engl Transl Denki Gakkai Ronbunshi) 135(3):56-63

146. Guglielmino E, Stammers $\mathrm{CW}$, Stăncioiu D, Sireteanu T, Ghigliazza R (2005) Hybrid variable structure-fuzzy control of a magnetorheological damper for a seat suspension. Int J Veh Auton Syst 3(1):34-46

147. Senaratne R, Hardy D, Vanderaa B, Halgamuge S (2007) Driver fatigue detection by fusing multiple cues, Lecture Notes in Computer Science, 4492 LNCS (PART 2), pp. 801-809 